\title{
Insect Community Structures of Bird's - Foot Trefoil (Lotus Corniculatus L.) Inflorescences Along the Seed Dispersal
}

\author{
Ana - Maria VIRTEIU ${ }^{1 *}$, Ioana GROZEA ${ }^{1}$, Ramona STEF ${ }^{1}$, Alin CARABET ${ }^{1}$, Teodora FLORIAN ${ }^{2}$ and Sne- \\ jana DAMIANOV ${ }^{1}$ \\ ${ }^{1}$ Department of Biology and Plant Protection, Banat's University of Agricultural Sciences and Veteri- \\ nary Medicine "King Michael I of Romania" from Timisoara 119 Calea Aradului, Timisoara, Romania; \\ ${ }^{2}$ Department of Environmental and Plant Protection, University of Agricultural Science and Veterinary \\ Medicine Cluj - Napoca 3 - 5 Calea Manastur, Cluj - Napoca, Romania; \\ * corresponding author: anamaria.badea@gmail.com
}

Bulletin USAMV series Agriculture 71(2)/2014

Print ISSN 1843-5246; Electronic ISSN 1843-5386

DOI 10.15835/buasvmcn-agr: 10631

\begin{abstract}
Bird's - foot trefoil (Lotus corniculatus L.) is an abundant Fabaceae species of grassland, which is also used as forage plants. Lotus corniculatus is an indeterminate flowering herbaceous perennial that, through the vegetative season, produces a great number of inflorescences. A long flowering period is a major factor limiting seed production in this plant. Despite the fact that these periods of flowering and seed dispersal are relatively short, the inflorescences at this period host the most abundant insect fauna. This present study was carried out with the objective to identify the commonly occurring insect's fauna and workout their abundance, diversity, habitat and food in Lotus corniculatus crop field from Banat (Timis, Romania): only Heteroptera are discussed. Insects were collected at monthly interval from May 2010 to September 2012 between 7.00 to 10.00 a.m. Extensive investigation was carried out in two localities, Timișoara and Gătaia, where 25 species of Heteroptera were identified in 29 samples containing 478 specimens. Miridae family was numerically the most abundant families constituting of $44.14 \%$ of all insects collected. Orius niger and Orius minutes is mentioned for the first time in the fauna of West Romania, as predators consuming thrips. The examined material includes six species of Heteroptera: Xylocoris galactinus Fieb., Cymus melanocephalus Ham., Geocoris grylloides L., Lioceris tripustulatus F., Orthops basalis, Orthops campestris L. that are relatively new for the fauna of Banat Region. Species diversity and evenness indices fluctuated from month to month and from one sampling site to other, and its abundance increases with the decreasing altitude of the locality.
\end{abstract}

Keywords: abundance, Heteroptera, inflorescences, Lotus corniculatus, species diversity

\section{INTRODUCTION}

The Heteroptera, or true bugs, is a highly diverse insect taxon with aproximately 42300 described species worldwide, separated into seven infraorders and 75 - 89 families (Rabitsch, 2010; Schuh and Slater, 1995).

Investigations of the Heteroptera of Banat were initiated by Hungarian naturalists and entomologists during the second half of the 19th century. Janos Frivaldszky (1877) recorded Heteroptera in some localities that today lie within the Hungarien - Serbian and Romanien borders
(Banat region). In 1897 and 1907, Geza Horvath (a noted entomologist and one of the greatest heteopterologist of Europe) published data on the disribution of Heteroptera in a number of localities in Banat.

As Heteroptera show a considerable differentiations in food diets, they can offer a good measure of biodiversity; the richness in species in this order is strongly related to the total insect diversity (Limonta et al., 2004; Duelli and Obrist, 1998). Most species are phytophagous, some feed exclusively on particular plant species, genera or 
families, whereas others are polyphagous species feeding on dozens to hundeds of different host plant (Schaefer and Panizzi, 2000).

Previous publications of this paper underlined species considerated harmful in various agricultural crops, so standing out the numerous information related to the environment and feeding spectrum of their lives (Beldean, 2004; Popov and Rosca, 1991; Rosca 1984; Perju and Schneider, 1972; Torma, 2009). One of the favorite crops of this Heteroptera is the birds - foot trefoil crop.

Bird's - foot trefoil (Lotus corniculatus) is one of the important and perspective crop in Romania, especially in recent years in relation to climate changes. This is an abundent perennial herbaceous plant that regularly produces many more flowers than mature fruits, and is native to Europe. It colonizes disturbed sites, pastures and temporary meadows, being cultivated both in pure culture and in different types of mixtures (Dragomir, 2005; Stephenson, 1984, 1986).

All of this requires enrichment and updating of knowledge for the Heteroptera species diversity and population density and also their predators. The purpose of the present contribution is to identify the commonly occurring insect's fauna and workout their abundance, diversity, habitat and food in Lotus corniculatus crop field from Banat (Timis, Romania): only Heteroptera are discussed.

\section{MATERIALS AND METHODS}

Insects in the present study were collected in 2010 - 2012 period, at monthly interval from May to September, between 7.00 to 10.00 a.m. Extensive investigation was carried out in two localities, Timișoara and Gătaia. Insects were colected with the help of sweep net method and some are hand picked. The heteroptera bugs were narcotized by using killing bottle and brought to the laboratory and preserved by dry preservation method. The adults were identified under stereozoom microscope with the use of various keys, the most important beeing the work of Cantoreanu (2007). During the period of investigation, 25 species of Heteroptera were identified in 29 samples containing 478 specimens; a sample represents the insects collected in 25 double mowings.

\section{Study region}

The Timisoara locality is located in the western part of Romania ( $45^{\circ} 74^{\prime}$ latitude, $21^{\circ} 22^{\prime}$ longitude), in the region called Banat. From a geomorphological point of view, the area is part of the great unit of the Banato - Crisane Plain, the territory belongs to the low plain sector, and is $89 \mathrm{~m}$ above sea level. The experience has been located on a brown - eutricambic soil, strong gleizat, gummy, with a $\mathrm{pH}=5,6$, hummus content of $2,56 \%$, cell phosphorus content of $24 \mathrm{ppm}$, cell potassium of $89 \mathrm{ppm}$ and nitrogen of 2,01\%.

The Gataia locality is located about $52 \mathrm{Km}$ of Timisoara ( $45^{\circ} 43^{\prime}$ latitude, $21^{\circ} 43^{\prime}$ longitude). The investigated region consist of farmland intersected in places by canals. The experience has been located on a gleizat aluviosoil, with a $\mathrm{pH}=$ 6,35 , hummus content of $1,73 \%$, cell phosphorus content of $6,3 \mathrm{ppm}$, cell potassium of $50 \mathrm{ppm}$ and nitrogen of $1,63 \%$.

The Banat region has a temperate continental climate-moderate, with an average annual temperature of $10.6^{\circ} \mathrm{C}$ and with a mean value of rain of $631 \mathrm{~mm}$ (Meteorological Station from Timisoara).

\section{RESULTS AND DISCUSSION}

The investigation of biodiversity of a group of insects is important because it establishes not only their numbers, but also the changes in the number of species in certain habitats (Protic, 2000).

The agroecosystems, particularly those in which is practiced an intensive agriculture have been changing fast during the last decades, affecting in that way the insect fauna structure, not only insects ar included, but also all living organisms.

In this context, our research will point out the structure of birds - foot trefoil insects fauna: only Heteroptera are discussed.

Heteroptera was the dominant insects group damaging birds - foot trefoil inflorescences.

The insects collected at Timisoara and Gataia represents a typical exemple of Heteroptera fauna present at sites of Banat region, western Romania. The sample of $2010-2012$ when all individuals were identified to species $(n=478)$ contained adults of 25 species, divided in 8 families (Tab. 1) of which the most abundent was the Miridae species Lygus pratensis L., $1758(n=68)$ which represents $14,23 \%$ of the total insects collected. Further dominant were one Anthocoridae specie, 
Tab. 1. Species of Heteroptera and number of specimen collected from birds - foot trefoil crops in the two localities

\begin{tabular}{|c|c|c|c|c|}
\hline Family & Species & Timisoara & Gataia & $\begin{array}{c}\text { Total number of } \\
\text { specimen }\end{array}$ \\
\hline Nabidae & Nabis ferus L., 1758 & 5 & 3 & 8 \\
\hline \multirow{4}{*}{ Anthocoridae } & Orius minutus L., 1758 & 25 & 10 & \multirow{4}{*}{120} \\
\hline & Orius niger Wolff, 1811 & 8 & 17 & \\
\hline & Anthocoris nemorum L., 1758 & 34 & 23 & \\
\hline & Xylocoris galactinus Fieber, 1861 & - & 3 & \\
\hline Cymidae & Cymus melanocephalus Fieber, 1861 & 1 & 2 & 3 \\
\hline Lygaeidae & Geocoris grylloides L., 1758 & 4 & - & 4 \\
\hline \multirow{8}{*}{ Miridae } & Liocoris tripustulatus Fabricius, 1781 & 4 & 2 & \multirow{8}{*}{211} \\
\hline & Halticus aptrus L., 1758 & 9 & 6 & \\
\hline & Adelphocoris lineolatus Goeze, 1778 & 16 & 32 & \\
\hline & Adelphocoris seticornis Fabricius, 1775 & 16 & 3 & \\
\hline & Lygus pratensis L., 1758 & 46 & 22 & \\
\hline & Lygus rugulipennis Poppius, 1911 & 8 & 9 & \\
\hline & Orthops basalis Costa, 1834 & 17 & 10 & \\
\hline & Orthops campestris L., 1758 & 3 & 8 & \\
\hline \multirow[b]{2}{*}{ Coreidae } & Centrocoris spiniger Fabricius, 1781 & 1 & 6 & \multirow{2}{*}{11} \\
\hline & Coreus marginatus L., 1758 & 4 & - & \\
\hline \multirow{7}{*}{ Pentatomidae } & Palomena prasina L., 1761 & 1 & - & \multirow{7}{*}{53} \\
\hline & Palomena viridissima Poda, 1761 & 5 & 2 & \\
\hline & Eurydema ornata L., 1758 - larve & 1 & - & \\
\hline & Dolycoris baccarum L., 1758 & 1 & 5 & \\
\hline & Eurydema oleracea L., 1758 & 16 & 12 & \\
\hline & Eurydema oleracea L. - larvae & 1 & 3 & \\
\hline & Piezodorus lituratus Fabricius, 1794 & 3 & 3 & \\
\hline \multirow{4}{*}{ Scutelleridae } & Eurygaster maura L., 1758 & 2 & 15 & \multirow{3}{*}{68} \\
\hline & Eurygaster austriaca Schranck., 1778 & 21 & 16 & \\
\hline & Eurygaster austriaca Schranck.- larvae & 9 & 5 & \\
\hline & & 261 & 217 & 478 \\
\hline
\end{tabular}

Anthocoris nemorum L., $1758(n=57)$ which represents $11,92 \%$ and one Miridae specie, Adelphocoris lineolatus Goeze, $1778(n=48)$ which represents $10,04 \%$.

Dominant were also the Scutelleridae species, Eurygaster austriaca Schranck., $1778(n=51)$, Pentatomidae species, Eurydema oleracea L., 1758 ( $n=32)$, Miridae species, Orthops campestris L., $1758(n=27)$ and two Anthocoridae species, Orius minutus L., $1758(n=35)$ and Orius niger Wolff, $1811(n=25)$.

One Scutelleridae (Eurygaster maura L., 1758) and four Miridae species were medium abundet ( $n$ $=10-23$ ), while thirteen remaining species were rare $(n=1-8)$.
The examined material includes six species of Heteroptera: Xylocoris galactinus Fieb., Cymus melanocephalus Ham., Geocoris grylloides L., Lioceris tripustulatus F., Orthops basalis, Orthops campestris L. that are relatively new for the fauna of Banat Region.

Adults of four species: Geocoris grylloides L., 1758; Coreus marginatus L., 1758, Palomena prasina L., 1761 and Eurydema ornata L., 1758 were found only in Timisoara locality, while one specie - Xylocoris galactinus Fieber, 1861 were found in Gataia.

During this study, larvae of several species of the family Pentatomidae and Scutelleridae were observed feeding in birds - foot trefoil inflorescences. 
Current knowledge on the zoogeographical distribution of the Banat Heteroptera can be considerated satisfacatory and the data lend themselves to same simple zoogeographical considerations excluding from the latter the 25 morphospecies.
Overall Heteroptera fauna of the area under study are characterized from the point of view zoogeographical as shown in Tab. 2.

Chorological categories were referred to the species level and based on classification proposed by Rabitsch and Waitzbauer (1996). The

Tab. 2. Main characteristics of Heteroptera collected from birds - foot trefoil crops in Banat region, 2010 -2012 period

\begin{tabular}{|c|c|c|c|c|c|}
\hline \multirow{2}{*}{ Classification } & \multicolumn{2}{|c|}{ Food } & \multirow{2}{*}{$\begin{array}{c}\text { Zoogeographic } \\
\text { distribution }\end{array}$} & \multicolumn{2}{|c|}{ Locality } \\
\hline & Zoo & $\mathrm{Ph}$ & & Timisoara & Gataia \\
\hline \multicolumn{6}{|l|}{ Nabidae } \\
\hline Nabis ferus L., 1758 & Pr, P & & N-Anatolian - European & $*$ & $*$ \\
\hline \multicolumn{6}{|l|}{ Anthocoridae } \\
\hline Orius minutus L., 1758 & Pr, P & & Palearctic & $*$ & $*$ \\
\hline Orius niger Wolff, 1811 & Pr, P & & Holopalearctic & * & $*$ \\
\hline Anthocoris nemorum L., 1758 & Pr, P & & Euro - siberian & * & $*$ \\
\hline Xylocoris galactinus Fieber, 1861 & $\mathrm{Pr}, \mathrm{P}$ & & Holopalearctic & & $*$ \\
\hline \multicolumn{6}{|l|}{ Cymidae } \\
\hline Cymus melanocephalus Fieber, 1861 & & $\mathrm{P}$ & Palearctic & $*$ & $*$ \\
\hline \multicolumn{6}{|l|}{ Lygaeidae } \\
\hline Geocoris grylloides L., 1758 & & $\mathrm{P}$ & Holomediterranean & $*$ & \\
\hline \multicolumn{6}{|l|}{ Miridae } \\
\hline Liocoris tripustulatus Fabricius, 1781 & & M & Euro - Siberian & $*$ & $*$ \\
\hline Halticus apterus L., 1758 & & 0 & Euro - Siberian & $*$ & $*$ \\
\hline Adelphocoris lineolatus Goeze, 1778 & & $\mathrm{P}$ & Holopalearctic & $*$ & $*$ \\
\hline Adelphocoris seticornis Fabricius, 1775 & & 0 & Paleartic & $*$ & $*$ \\
\hline Lygus pratensis L., 1758 & & $\mathrm{P}$ & Holopalearctic & $*$ & $*$ \\
\hline Lygus rugulipennis Poppius, 1911 & & $\mathrm{P}$ & Holopalearctic & * & $*$ \\
\hline Orthops basalis Costa, 1834 & & 0 & Holomediterranean & $*$ & $*$ \\
\hline Orthops campestris L., 1758 & & 0 & Palearctic & $*$ & $*$ \\
\hline \multicolumn{6}{|l|}{ Coreidae } \\
\hline Centrocoris spiniger Fabricius, 1781 & & $\mathrm{P}$ & Euro - Mediterranean & $*$ & $*$ \\
\hline Coreus marginatus L., 1758 & & $\mathrm{P}$ & Palearctic & $*$ & \\
\hline \multicolumn{6}{|l|}{ Pentatomidae } \\
\hline Palomena prasina L., 1761 & & $\mathrm{P}$ & Holopalearctic & $*$ & \\
\hline Palomena viridissima Poda, 1761 & & $\mathrm{P}$ & Euro - Siberian & $*$ & $*$ \\
\hline Eurydema ornata L., 1758 & & 0 & Holopalearctic & & $*$ \\
\hline Dolycoris baccarum L., 1758 & & $\mathrm{P}$ & Holopalearctic & $*$ & $*$ \\
\hline Eurydema oleracea L., 1758 & & 0 & Euro - Siberian & * & $*$ \\
\hline Piezodorus lituratus Fabricius, 1794 & & $\mathrm{P}$ & Palearctic & $*$ & $*$ \\
\hline \multicolumn{6}{|l|}{ Scutelleridae } \\
\hline Eurygaster maura L., 1758 & & 0 & Euro - Siberian & $*$ & $*$ \\
\hline Eurygaster austriaca Schranck., 1778 & & 0 & $\begin{array}{l}\text { Mediterranean witch } \\
\text { also occurs in Central } \\
\text { Europe }\end{array}$ & $*$ & $*$ \\
\hline
\end{tabular}

Explanations: Zoo - zoophagous, $\mathrm{Ph}$ - Phytophagous, $\mathrm{Pr}$ - predator, $\mathrm{P}$ - polyphagous, $\mathrm{O}$ - oilgophagous, $\mathrm{M}$ - monophagous 
Tab. 3. Occurrence of Heteroptera species in birds - foot trefoil crop with respect to zoogeographical regions

\begin{tabular}{lcc}
\hline Zoogeographic distribution & No. species & Occurrence $\%$ \\
\hline Euro - Mediterranean & 7 & $1,46 \%$ \\
\hline N-Anatolian - European & 8 & $1,67 \%$ \\
\hline Holomediterranean & 31 & $6,49 \%$ \\
\hline Mediterranean & 51 & $10,67 \%$ \\
\hline Palearctic & 78 & $16,32 \%$ \\
\hline Euro - Siberian & 134 & $28,03 \%$ \\
\hline Holopalearctic & 169 & $35,36 \%$ \\
\hline
\end{tabular}

distribution are deduced from Linnavuori (2011), Ghahari et al. (2009) and others more recent reviews above mentioned.

As far as chorology is concerned there are 8 Holopaleartic species, 6 Paleartic species, 6 Euro - siberian species, 2 Holomediterranean species, 1 Mediterranean species, 1 Euro - mediterranean species and $1 \mathrm{~N}$ - Anatolian - European species.

Considering the type of diet, the are 5 predator species, 11 phytophagous species, 8 oligophagous species and 1 monophagous species.

In both locality, Timisoara and Gataia, the minute pirate bugs Orius minutus L., 1758 and Orius niger Wolff, 1811, and common flowerbug Anthocoris nemorum L., 1758, predators of insects and mites, was frecquently collected oh birds foot trefoil inflorescences. Orius niger and Orius minutes is mentioned for the first time in the fauna of West Romania, as predators consuming thrips. The presence in both environments is due to the ability of Anthocoridae to tolerate pesticides, probably thanks to the high mobility and to the large number of generations (Fauvel, 1999).

Other predators present in both locality are field damsel bug Nabis ferus L., 1758, species not infuenced by intensive management og birds foot trefoil crops (Limonta et al., 2004), it is spread all over Banat region on birds - foot trefoil plants and also on herbs.

Mirids are more abundent in Timisoara and in fact they seem to be more linked to the host plant and more susceptible to the effect of chemical sprays than anthocorids (Limonta et al., 2004; Fauvel, 1999). Among phytophagous mirids, Halticus apterus L., 1758 is a common species, that colonize besides Lotus corniculatus inflorescences, other Fabaceae and Galium species.
Adelphocoris lineolatus, Lygus pratensis, Lygus rugulipennis, Palomena prasina, Dolycoris baccarum, Piezodorus lituratus, all phytophagous, are common species and they can be pests of many crops (Balarin, 1978; Southwood and Leston, 1959).

An analysis of the zoogeographical distribution of the Heteroptera of birds - foot trefoil crops from Banat region (Tab. 3) shows at the first evaluation that the species with great ranges (Paleartic, Euro - Siberian and Holopaleartic), comprise 381 species, or $79,71 \%$ of the total Heteroptera fauna. Also typical of the Heteroptera fauna of birds - foot trefoil crop is a great number of the Mediterranean species, which comprise both exclusively Mediterranean species, and those whose ranges include a Mediterranean element. So, a total of "Mediterraneans" is estimated at 89 species, or $18,62 \%$ of the total Heteroptera fauna from brird - foot trefoil crops in Banat regions.

\section{CONCLUSION}

1. Heteroptera was the dominant insects group damaging birds - foot trefoil inflorescences.

2. During the two yeares 478 adults of Heteroptera were colected. They belong to 25 species, divided in 8 families.

3. The most abundent was the Miridae species Lygus pratensis which represents 14,23\% of the total insects collected.

4. Six species of Heteroptera: Xylocoris galactinus Fieb., Cymus melanocephalus Ham., Geocoris grylloides L., Lioceris tripustulatus F., Orthops basalis, Orthops campestris L. are relatively new for the fauna of Banat Region.

5. As far as chorology is concerned there are 8 Holopaleartic species, 6 Paleartic species, 6 Euro - siberian species, 2 Holomediterranean species, 
1 Mediterranean species, 1 Euro - mediterranean species and $1 \mathrm{~N}-$ Anatolian - European species.

6. Considering the type of diet, the are 5 predator species, 11 phytophagous species, 8 oligophagous species and 1 monophagous species.

7. Species diversity and evenness indices fluctuated from month to month and from one sampling site to other, and its abundance increases with the decreasing altitude of the locality.

\section{REFERENCES}

8. Alzugaray Rosario (2003). Insect pests damaging Lotus corniculatus L. flowers and seeds in Uruguay, Lotus Newsletter, 33:11 - 18

9. Balarin I., 1978 - Prilog poznavanju Heteroptera u fauni lucerista jadranskog podrucja, Poljoprivredna Znanstvena Smotra, 45 (55): 119 - 129 (english summary)

10. Beldean P.V., 2004 - Studiul faunistic, ecologic si zoogeografic al suprafamiliei Pentatomoidea (Heteroptera, Insecta) in zona localitatii Rimetea (jud. Alba), Bul. inf. Entomol., 14 - 15:147 - 155 (in Romanian)

11. Cantoreanu M., 2007 - Ordinul Hemiptera - In: Moldovan O.T. (ed.): Lista Faunistica a Romaniei (specii terestre si de apa dulce), Casa Cartii de Stiinta, Cluj - Napoca, 237 - 262 pp (in Romanian)

12. Dragomir N., 2005 - Pajişti şi plante furajere. Tehnolgii de cultivare, Ed. Eurobit, Timişoara

13. Duelli P., Obrist M.K., 1998 - In search of the best correlates for local organismal biodiversity in cultivated aeas, Biodiversity and Conservation, 7:297 - 309

14. Fauvel G., 1999 - Diversity of Heteroptera in agroecosystems:role of sustainability and bioindication. - Agriculture, Ecosystem and Environment, 74: 275 - 303

15. Frivaldszky J., 1877 - Adatok Temeseskrassimegyek Faunajahoz. Közlemenyek, 13:371 - 377 (in Hungarian)

16. Ghahari H., Carpintero D.L., Ostovan H., 2009 - An annotated catalogue of the Iranian Anthocoridae (Hemiptera: Heteroptera: Cimicomorpha), Acta Entomologica Musei Nationalis Pragae, 49 (1): 43 - 58

17. Horvath G., 1897 - Fauna regni Hungariae. Animalium Hungariaehucusque cogitorum enumeratio systematica 111. Arthropoda ordo: Hemiptera, Budapest, 72 pp. (in Hungarian and Latin)

18. Horvath G., 1907 - Supplementum ad Faunam Hemipterorum regni Hungariae. Annales Musei Nationalis Hungarici, 5:500 - 506 (in Hungarian)
19. Limonta L., Dioli P., Bonomelli N., 2004 - Heteroptera on flowering spontaneous herbs in differently managed orchards, Boll. Zool. agr. Bachic., ser. II, 36(3):355 - 366

20. Linnavouri R.E., 2011 - Studies on the Cimocomorpha and Pentatomorpha (Hemiptera: Heteroptera) of Khuzestan and the adjacent provinces of Iran, Acta Entomologica Musei Nationalis Pragae, 51 (1): 21 - 48

21. Perju T., Schneider E., 1972 - Contributii la cunoasterea faunei de Heteroptere din culturile de legumionase perene din Transilvania de Nord - Vest. Muzeul Brukenthal Studii si comunicari - Stiintele Naturii, 17:277 - 289 (in Romanian)

22. Popov C. And Rosca I., 1991 - Recent research regarding cereal bugs (Eurigaster ssp.) in Romania, Revue Roumaine de Biologie, Ser. Biol. Anim., 36(1 - 2):51 - 56

23. Protic L.J., 2000 - Biodiversity of the Heteroptera of Serbia, Acta ent. Serb., 5 (1/2): 1 - 12

24. Rabitsch W., 2010 - True bugs (Hemiptera, Heteroptera). Chapter 9.1, BioRisk 4(1):407 - 433

25. Rabitsch W., Waitzbauer W., 1996 - Beitrag zur Wanzenfauna (Insecta: Heteroptera) von Xerothermstandorten im östlichen Niederösterreich, Verh. Zool. - Bot. Ges. Österreich 133: 251 - 276

26. Rosca I., 1984 - Zoogeographic analysis of the fauna of terrestrial Heteroptera from Romania. Revue Roumaine de Biologie, Ser. Biol. Anim., 29(1):77 - 80

27. Schaefer and Panizzi, 2000 - Heteroptera of economic importance. Boca Raton, Florida: CRC Press, 828 pp.

28. Schuh R.T., Slater J.A., 1995 - True bugs of the world (Hemiptera: Heteroptera) classificaion and natural history. Cornell Unive. Press, Ithaca, NY and London, 336 pp.

29. Southwood T.R.E., Leston D., 1959 - Land and water bugs of the British Isles. Frederick Warne and Co. LTD, London and New York, $544 \mathrm{pp}$.

30. Stephenson A. (1984). The regulation of maternal investment in an interdeterminate flowering plant (Lotus corniculatus), Ecology, 65(1): 113 - 121

31. Stephenson A. and Winsor J. (1986). Lotus corniculatus regulates offspring quality through selective fruit abortion, Evolution, 40(3): 453 - 458

32. Torma A., 2009 - Data to the terrestrial Heteroptera fauna of Moldova, Acta Scientiarum Transylvanica, 17(1): 105 118 